Original research article

\title{
Exergetic assessment of municipal solid waste management system in south Beijing
}

\author{
Chuanbin Zhou, Dan $\mathrm{Hu}^{*}$, Rusong Wang, Jingru Liu \\ State Key Laboratory of Urban and Region Ecology, Research Center for Eco-Environmental Science, Chinese Academy of Sciences, 18 Shuangqing Road, 100085 , \\ Haidian District, Beijing, China
}

\section{A R T I C L E I N F O}

\section{Article history:}

Received 25 September 2010

Received in revised form 18 December 2010

Accepted 8 January 2011

Available online 26 February 2011

\section{Keywords:}

Exergy analysis

Municipal solid waste

Exergetic efficiency

South Beijing

\begin{abstract}
A B S T R A C T
The exergetic analysis model of municipal solid waste (MSW) was established to study the MSW management system in south Beijing. The materials and energy inventory of different processes, including transport, mechanical separation, compost, incineration and landfill, were analyzed. Based on the inventory analysis, the exergetic efficiencies of different unit technologies and management systems were studied, and the main results were: (1) the exergetic efficiency of compost and incineration is $5.98 \%$ and $14.23 \%$, higher than landfill, $2.92 \%$; (2) mechanical separation increases the exergetic efficiency of unit technologies, from $2.92 \%$ to $4.33 \%$ of landfill and from $14.23 \%$ to $15.59 \%$ of incineration; and ( 3 ) integrated treatment increases the comprehensive exergetic efficiency of the MSW management system, exergetic efficiency of MSW management system in south Beijing increased from $2.91 \%$ to $4.57 \%$ because the processes of mechanical separation and compost were introduced, furthermore, when the incineration facility is applied to treat the plastic and paper, exergetic efficiency of the system will increase to $13.95 \%$. According to the exergetic analysis, HRRIS aims (harmless, recycling, reductive, industrializing and socializing) of MSW management system were put forward, and scavenger management, charging mechanism and integration of technologies were discussed.
\end{abstract}

(c) 2011 Elsevier B.V. All rights reserved.

\section{Introduction}

Municipal solid waste (MSW) management system is a complex system that contains social economic and environmental factors (Banar et al.). Different materials and energies were intertransformed through processes, and the harmless, recycling, reductive, industralizing and socializing aims were expected to be completed. Thus methods of systemic assessment are essential to research the MSW management.

Life cycle analysis (LCA) method was widely practiced for systemically assessing MSW management systems. Life cycle inventory analysis of resources, energies and pollutants emissions is the first phase to determine the emission patterns within the system; some studies also involved economic and welfare factors into the life cycle inventory (Eriksson et al., 2005). And then the environmental impact potentials of global warming, acidification, nutrient enrichment and ecotoxity are calculated (Banar et al.; Xu et al., 2000; Eriksson et al., 2005; Chen and Lin, 2008). Some LCA models with friendly human-computer interface have been developed to assist the decision-making of MSW management and proved successful, such as Integrated Waste Management

\footnotetext{
* Corresponding author. Tel.: +861062849199.

E-mail address: hudan@rcees.ac.cn (D. Hu).
}

(IWM) model, Waste Reduction Model (WARM), Organic Waste Research model (ORWARE) and WASTED model (Diaz and Warith, 2006; Oeler et al., 2006). Analytic hierarchy process (AHP) model, multi-decision making model and geography information system (GIS) were used to overcome the difficulties of temporal and spatial analysis of LCA (Shmelev and Powell, 2006; Contreras et al., 2008). Though such useful improvements were made, there are still some difficulties of LCA method, for example, comparison among environmental impacts, cost and social benefits may be determined by subjective weights. The environmental impact potential of LCA does not have any physical signification, and analyzing the benefits of resource recovering was found to be difficult (Brown and Buranakarn, 2003).

Emergy and exergy analyses are used to assess the resources' transforming efficiency and sustainability, and they are always integrated with life cycle inventory analysis (Li and Wang, 2009). Emergy analysis has been introduced in researching the recycling processes of municipal solid waste and demolition waste. Energies, materials, labors and investments are unified into solar emergy joules (sej) by their emergy transformity to research systemic efficiency (Lei and Wang; Brown and Buranakarn, 2003; Marchettini et al., 2007). Dewulf assessed waste recycling processes with exergy method to quantify the systemic sustainability in industrial ecology perspective (Dewulf and Langenhove, 2002, 2005). Both emergy and exergy can reflect the quality of energy inhered in the 
resources, thus can unify different types of resources and used as a systemic assessing tool. Nevertheless, emergy is appropriate to study the large scale systems, such as ecological and urban systems, while exergy is appropriate to study comparatively small scale processes, such as power plants and bio-ethanol productions (Sciubba and Ulgiati, 2005). Improvements of exergy analysis have been made to study more complex systems, for example, extended exergy accounting including externalities of exergy resources, thus providing possibility to study the biodiversity, ecological services and social-economic-natural complex ecological systems (Dewulf et al., 2000, 2001; Nielsen, 2007; Jogensen, 2010; Petrovskaya et al., 2006).

The exergy analysis model was studied to assess MSW management system in south Beijing. Inputs and outputs of exergy resources of different processes were listed in the inventory and calculated the exergy consumption, such as materials (food waste, paper, plastic, methane, compost, etc.), energies (coal, electricity, diesel, etc.) and labors. The exergetic efficiencies of MSW management systems and unit treatment technologies (landfill, compost and incineration) were studied; moreover, the impacts on systemic exergetic efficiency due to the social phenomena of rubbish collectors (scavengers) and relative policies were discussed.

\section{Methods}

\subsection{Exergy analysis}

The second law of thermodynamics says every process has a degradation toward entropic, in other words, the quality of energy decreases. Exergy is the maximum work that can be obtained from materials, so it can be expressed as "useful energy" and reflect the quality of energy. The implication of exergy is expressed in forum (1).

$e_{1}=h_{1}-h_{0}-T_{0}\left(s_{1}-s_{0}\right)$

where: $e_{1}$, exergy; $h_{1}, h_{0}$, specific enthalpy; $T_{0}$, temperature; $s_{1}, s_{0}$, specific entropy.

Cumulative exergy consumption (CExC) derived from the concept of exergy. It can be quantified that the exhausted resources and energy to obtain some products or service, and the CExC of different resources and energies are additive. Procedure for exergy accounting is: (1) define the control boundary; (2) draw a detailed flow chart of the system; (3) establish a library of CExC of each process and classify the useful and useless products; (4) define the thermodynamic state; (5) perform a mass and energy balance; (6) study the exergy balance of each process; (7) compute the exergetic efficiency of each process or system (Sciubba and Ulgiati, 2005), that is the ratio of all the exergy outputs and inputs. The method to compute exergetic efficiency of the MSW management system was shown in forum (2).

$\eta=\frac{\sum_{\text {useful }} O_{k}}{\sum_{j} I_{j}}=\frac{O_{\text {methane }}+O_{\text {compost }}+O_{\text {heat }}}{I_{\text {waste }}+I_{\text {energy }}+I_{\text {labour }}}$

\subsection{Study area}

There are two important parts of municipal solid waste management: (1) the commercial department is in charge of the recyclables' collection, recycling and remanufacturing; (2) the municipal administration committee is in charge of the transport, separation, compost, incineration and landfill of the municipal solid waste, which is deemed to be useless and only has a small part of recyclables. Materials flow of MSW management system is

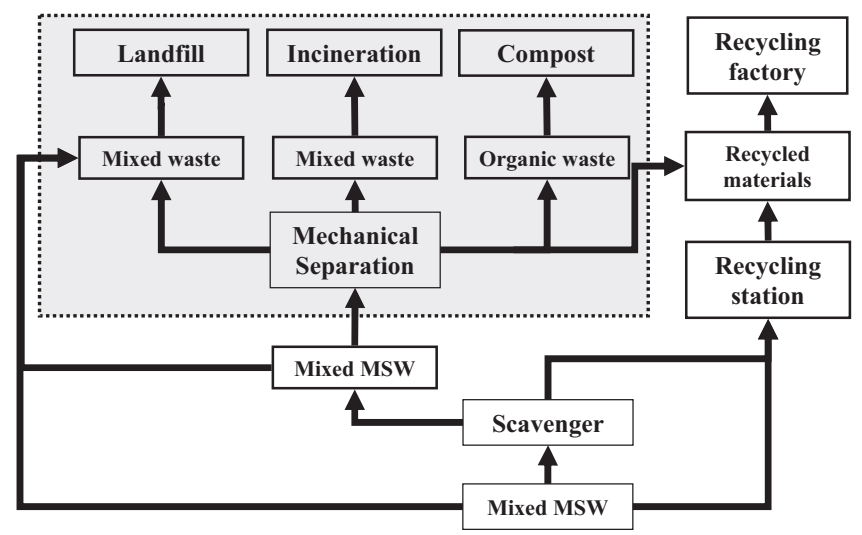

Fig. 1. Flow of MSW treatment system.

shown in Fig. 1. The exergy inputs of the MSW management systems include solid wastes, energy and labor, while the exergy outputs include methane, heat and compost.

MSW management system in south Beijing (Xuanwu District and Fengtai District) is studied. These two districts produce about 1900 tons of waste/day. Currently, there are three MSW treatment facilities: Majialou transfer and separation station with capacity of 1100 tons/day, Nangong compost facility with capacity of 600 tons/day, and Anding landfill with capacity of 1300 tons/day; and an incinerator with capacity of 1000 tons/day has been planned. The Majialou transfer and separation station was built in year 2002 and designed to separate solid waste into three categories by their diameters: (1) $<15 \mathrm{~mm}$, the main composition is dirt, ash and a small part of organics; (2) from 15 to $60 \mathrm{~mm}$, most of this part is organics; (3) more than $60 \mathrm{~mm}$, the main composition is plastic, paper and organics. Currently, solid waste with the diameter from 15 to $60 \mathrm{~mm}$ (226 tons/day) was send to the Nangong compost facility, while other parts (874 tons/day) were sent to the Anding landfill. According to the MSW treatment plan, when the incinerator is used, solid waste larger than $60 \mathrm{~mm}$ is supposed to be incinerated, the combusted ash and solid waste smaller than $15 \mathrm{~mm}$ are disposed in Anding landfill (149 tons/day). Exergetic transforming efficiency of different MSW management systems in south Beijing was researched: S1 is the system before year 2002, solid waste was disposed in landfill without mechanical separation and compost; S2 is the system at present, solid waste was mechanically separated, and medium sized solid waste was composted; and S3 is the proposed system, where an incinerator will be introduced to treat large sized solid waste.

\subsection{Numerical model of treatment process}

$W$ is the weight of processed solid waste $\left(W_{T}\right.$, transport; $W_{S}$, separation; $W_{L}$, landfill; $W_{C}$, compost; $W_{l}$, incineration), $c_{i}, d_{i}$ and $w_{i}$ are proportion, degradable organic component (DOC) and moisture of different kinds of composition, where $i=1,2,3,4,5,6,7$ refers to food waste, paper, plastic, glass, dirt and ash, metal and wood.

(1) Transport and mechanical separation: exergy inputs are electricity, diesel and labor, no exergy output.

(2) Landfill: main product is methane, calculated with formula (3) (IPCC, 2000, 2001) and (4). About $80 \%$ of methane could be collected in the landfill site.

$W_{\text {methane }}=W_{L} \times \mathrm{MCF} \times \mathrm{DOC} \times \mathrm{DOC}_{F} \times F \times \frac{16}{12}$

$D O C=\sum c_{i} \cdot d_{i} \cdot\left(1-w_{i}\right)$ 
where $W_{L}=$ total MSW disposed to landfill sites; $\mathrm{MCF}=$ methane correction factor ( 1.0 for sanitary landfill); $\mathrm{DOC}=$ degradable organic carbon; $\mathrm{DOC}_{F}=$ fraction $\mathrm{DOC}$ dissimilated $(0.014 T+0.28=0.77$, $T=35$ ); $F=$ fraction of methane in landfill gas (default 0.5 ).

(3) Incineration: main product is heat, calculated with formula (5) and (6) (Rand et al., 2000).

$E_{\text {heat }}=\varepsilon \cdot \sum W_{I} \cdot c_{i} \cdot$ LHV

$\mathrm{LHV}_{i}=\mathrm{HHV}_{i} \cdot C_{i}-w_{i} \cdot 2445$

where $E_{\text {heat }}=$ heat recovered from the incineration facilities; $\varepsilon=$ efficiencies of energy recover systems $(80 \%$, system only recover heat); $\mathrm{LHV}_{i}=$ low heat value of different waste; $\mathrm{HHV}_{i}=$ high heat value of different waste; $C_{i}=$ combustibles of different waste (\%).

(4) Compost: main product is compost, which could be calculated with formula (7).

$W_{\text {compost }}=\alpha \cdot W_{C}$

where $W_{\text {compost }}=$ the weight of compost; $\alpha=$ transfer efficiency from organic waste to compost ( $25 \%$ in practice).

\subsection{Cumulative exergy consumption}

Extraction of resources out of the ecosphere, transport and labor are considered in order to compute the total cumulative exergy consumption (CExC) for solid waste recycling and treatment. A library of the CExC of materials and energies and their reference are given in Table 1 . Fresh water has been selected as the reference state of zero exergy content.

\section{Results}

\subsection{Input and output of CExC}

The inputs and outputs of exergy resource were calculated (see Table 2). The exergetic transforming process is determined by the characteristics of solid waste. The composition, moisture, DOC and high heat value of different sized solid waste in south Beijing were mentioned in Appendix A. The main productions of solid waste treatment processes were determined by formula (4)-(7). According to the calculation, the most important exergetic input was solid waste, which accounts for 95.8-99.6\% of the total exergetic inputs. The exergetic input of plastic is about $15,000 \mathrm{GJ}$, which is the highest among all the components of solid waste; the exergetic inputs of food waste and paper are $7413.2 \mathrm{GJ}$ and $1240.9 \mathrm{GJ}$, which are lower than plastic; the exergetic inputs of glass, dirt and ash, metal and wood are $<500 \mathrm{GJ}$, which are much lower than plastics, food waste and paper.
When the different unit technologies, mechanical separation, compost, incineration and landfill, were integrated and the systems were improved from S1 to S2 and S3, the output of exergy increased from 743.2 GJ to $1173.6 \mathrm{GJ}$ and $3699.8 \mathrm{GJ}$, though the accessorial exergy inputs of transport, energies and labor increased from $65.4 \mathrm{GJ}$ to $236.4 \mathrm{GJ}$ and $1120.3 \mathrm{GJ}$ in the same time. In the view of exergetic resource recovering, these improvements are totally worthy because the accessory inputs are much lower than the exergetic output of solid waste.

\subsection{Exergetic efficiency of different treatment systems}

When mechanical separation, compost, incineration and landfill were integrated and the systems were improved from S1 (landfill) to S2 (separation, compost and landfill) and S3 (separation, compost, incineration and landfill), the exergetic efficiency of different systems increases (see Fig. 2). As shown in Fig. 2, the main results are: (1) the exergetic efficiency of S1 was the lowest among these three systems, only $2.92 \%$. (2) S2 separated $15-60 \mathrm{~mm}$ sized organics from solid waste and composted, the organics can be recycled in a more efficient way, thus the exergetic efficiency of S2 increase to $4.57 \%$. Although other solid waste were separated into $15 \mathrm{~mm}$ undersized and $60 \mathrm{~mm}$ oversized, they were mixed again and landfilled because of lacking further treatment facilities; (3) S3 adds an incinerator to S2, solid waste larger than $60 \mathrm{~mm}$ (most of them are plastic, paper and food waste) is combusted, the energy inherent in plastics and papers can transform to heat, which is then transformed into electricity. Thus the exergetic efficiency will increase to $13.95 \%$ in the future.

\subsection{Exergetic efficiency of different processes}

Three main processes, landfill, compost and incineration, are considered. The exergetic efficiency of different solid waste treatment processes is impacted by the characteristics of solid waste. Each process is best suited for certain kind of solid waste in the view of exergetic transformation. In the south Beijing's case, solid waste has separated into three different sizes; the exergetic efficiency of each process treating different sized solid waste is shown in Table 3 . Landfill with mixed solid waste obtain a lowest exergetic efficiency of $2.92 \%$, but when the medium sized (15-60 mm) solid waste was separated, the exergetic efficiency of landfill increased to $4.33 \%$. If the solid waste larger than $60 \mathrm{~mm}$ is separated from landfill process, the exergetic efficiency increases to $10.90 \%$. This is because that most of this part is plastics and papers, which have very high cumulative exergy consumption but have little impact on methane production in the landfill process. The same result comes to incineration processes of different kinds of solid waste. Comparing the incineration of mixed solid waste and the

\section{Table 1}

Resources and utilities required for the MSW treatment system.

\begin{tabular}{|c|c|c|c|c|}
\hline $\mathrm{I} / \mathrm{O}$ & Material and energy & CExC & Unit & Reference \\
\hline \multirow[t]{12}{*}{ Input } & Food & 15.5 & $\mathrm{MJ} / \mathrm{kg}$ & Wall (1986) \\
\hline & Paper & 69.16 & $\mathrm{MJ} / \mathrm{kg}$ & Finnveden et al. (2005) \\
\hline & Plastic & 86 & $\mathrm{MJ} / \mathrm{kg}$ & Dewulf and Langenhove (2002) \\
\hline & Glass & 33.4 & $\mathrm{MJ} / \mathrm{kg}$ & Szargut et al. (1988) \\
\hline & Stone and ash & 1.1 & $\mathrm{MJ} / \mathrm{kg}$ & Dewulf et al. (2001) \\
\hline & Metal & 45.9 & $\mathrm{MJ} / \mathrm{kg}$ & Szargut et al. (1988) \\
\hline & Wood & 13.3 & $\mathrm{MJ} / \mathrm{kg}$ & Wall (1986) \\
\hline & Electricity & 11.27 & $\mathrm{MJ} / \mathrm{kWh}$ & Szargut et al. (2002) \\
\hline & Coal & 22.6 & $\mathrm{MJ} / \mathrm{kg}$ & Szargut et al. (2002) \\
\hline & Diesel & 53.2 & $\mathrm{MJ} / \mathrm{kg}$ & Wall (1986) \\
\hline & Tansport & 4.33 & $\mathrm{MJ} / \mathrm{km}$ & Dewulf et al. (2001) \\
\hline & Labor & 52.7 & $\mathrm{MJ} \cdot(\operatorname{man}-1 \cdot \mathrm{h})-1$ & Sciubba (2001) \\
\hline \multirow[t]{3}{*}{ Output } & Compost & 4.36 & $\mathrm{MJ} / \mathrm{kg}$ & Dewulf et al. (2001) \\
\hline & Methane & 51.98 & $\mathrm{MJ} / \mathrm{kg}$ & Szargut et al. (1988) \\
\hline & Electricity & 11.27 & $\mathrm{MJ} / \mathrm{MJ}$ & Szargut et al. (2002) \\
\hline
\end{tabular}




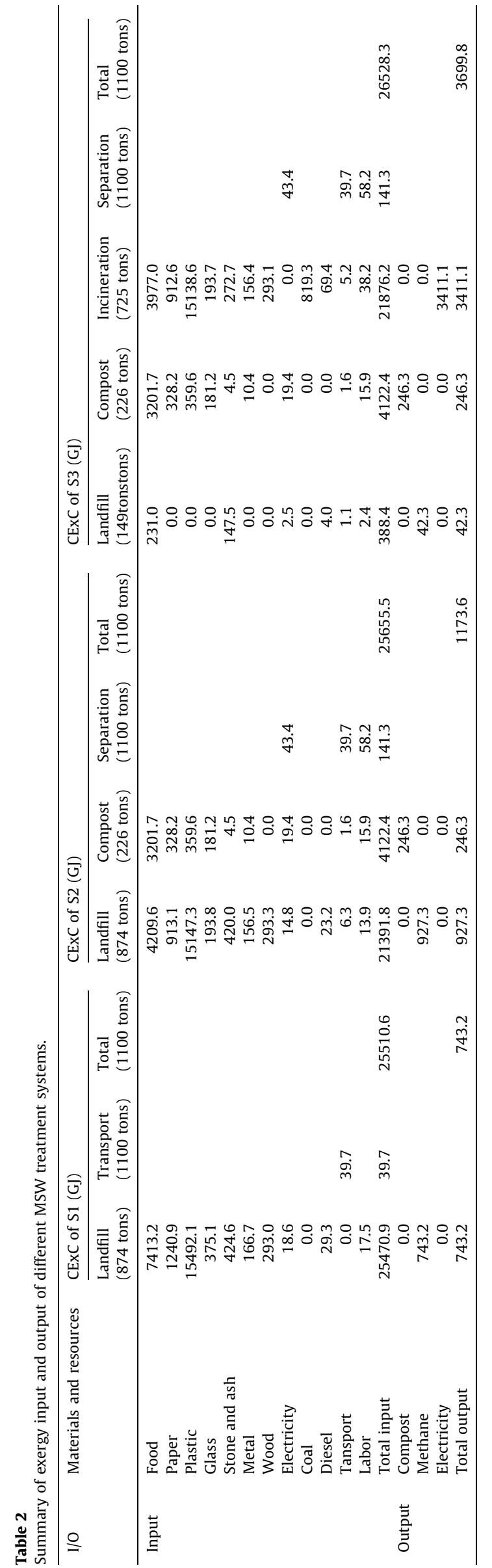

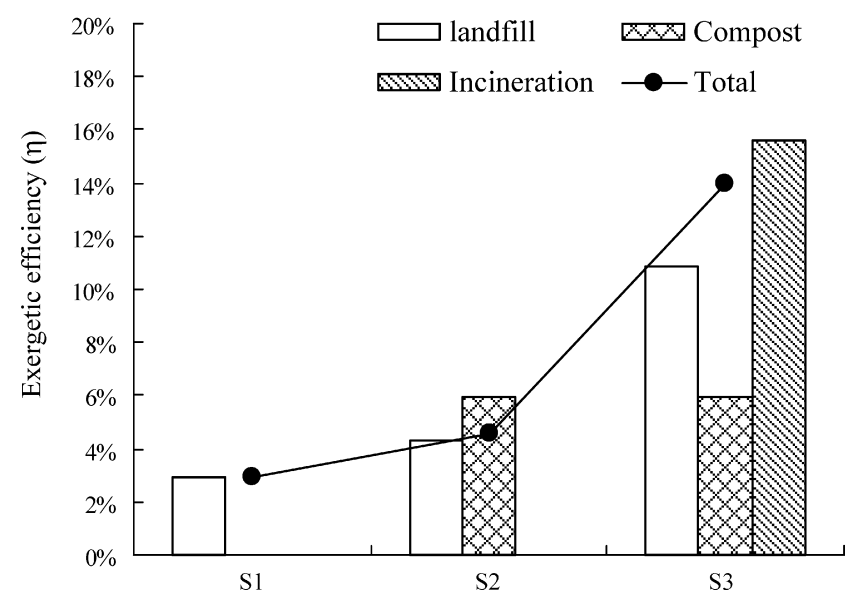

Fig. 2. Exergy efficiency of different treatment systems.

waste larger than $60 \mathrm{~mm}$, the exergetic efficiency of the latter is $15.59 \%, 1.1$ times higher than the former. Comparing these three processes, we found that the exergetic efficiency of incineration was higher than compost and landfill. The exergetic input of plastics is about $15,000 \mathrm{GJ}$, almost accounts for $70 \%$ of the total exergetic inputs of processed solid waste, and incineration is the only way to transform the most exergetic inputs of plastics into energy.

\section{Discussion}

MSW management system under "Business as usual (BAU)" model was aimed at harmless treatment of the solid wastes; the exergetic efficiency of BAU was lower than $5 \%$. Based on the exergetic analysis, an MSW management system with harmless, recycling, reductive, industrializing and socializing aims was put forward (HRRIS). Harmless, recycling and reductive are the basic requirements of all MSW management systems. These aims could be enhanced by constructing an integrating system of different technologies at the end. Industrializing and socializing aims focuses on integrating the industrial chains and publics into MSW management system. The first thing is to reserve and recreate the existing elements, such as scavengers and charging mechanism. There are closing relationship and similar microcosmic mechanism between exergy and economy-society system, thus exergy could play an important role in analyzing the economic and social issues of MSW management system. According to the results of exergetic analysis, some policies and managing suggestions were made to increase the exergetic efficiency and promote the HRRIS aims of the MSW management system in south Beijing.

\subsection{Management of scavengers}

Separations in different phases (at the source, transport, recycling sites and the treating end) promote the recycling potential of exergy resources. Rubbish collectors, in other words scavengers, play an important role in recycling MSW in China and other developing countries in Asia and South America (Medina,

Table 3

The exergetic efficiencies of different processes.

\begin{tabular}{llccr}
\hline Process & Separation & CExC input $(\mathrm{GJ})$ & CExC output $(\mathrm{GJ})$ & $\eta(\%)$ \\
\hline \multirow{2}{*}{ Landfill } & Mixed & 25470.9 & 743.2 & 2.92 \\
& $<15$ and $>60 \mathrm{~mm}$ & 21391.8 & 927.3 & 4.33 \\
& $<15 \mathrm{~mm}$ & 388.4 & 42.3 & 10.90 \\
Compost & $15-60 \mathrm{~mm}$ & 4122.4 & 246.3 & 5.98 \\
Incineration & Mixed & 26792.1 & 3812.3 & 14.23 \\
& $>60 \mathrm{~mm}$ & 21876.2 & 3411.1 & 15.59 \\
\hline
\end{tabular}


2000). According to recent estimation, there are 130,000 scavengers in Beijing city. Most of them belong to the floating population and live on collecting and selling recyclable resources.

We have studied separating processes of scavengers in the community, and the main results are: (1) recyclable resources that could be collected/inhabitant/day by scavengers are: cardboard, $10.57 \mathrm{~kg} 10^{-3}$ capita $^{-1} \mathrm{~d}^{-1}$; newspaper, $7.27 \mathrm{~kg} 10^{-3}$ capita $^{-1} \mathrm{~d}^{-1}$; plastic, $0.83 \mathrm{~kg} 10^{-3}$ capita $^{-1} \mathrm{~d}^{-1}$; (2) average separating efficiency of a scavenger is $0.64 \mathrm{~kg}$ (waste) capita ${ }^{-1} \mathrm{~min}^{-1}$. According to these experiment datum, we could estimate that the recyclable resources collected by scavenger in south Beijing is 21.1 tons of cardboard, 14.5 tons of newspaper and 1.66 tons of PET plastic bottles, and the population of scavengers is about 6.2 thousand.

Dewulf has computed that the exergetic efficiencies of remanufacturing cardboard, newspaper and PET plastic are $36.1 \%, 47.1 \%$ and 83.5\%, respectively (Dewulf and Langenhove, 2002). The exergy input of manual separation of scavengers is estimated of $326.7 \mathrm{GJ}$ (6.2 thousand people's daily labor, $8 \mathrm{~h} \mathrm{capita}^{-1} \mathrm{day}^{-1}$ ). Even considering the labor inputs, the exergetic efficiency of collecting and remanufacturing cardboard, newspaper and PET plastic is expected to reach $50.0 \%$, which is much higher than the incinerating processes (cardboard and newspaper, 7.1\%; plastic, 18.7\%). Although scavengers could assist the remanufacturing system to obtain higher exergetic efficiency, there are still many disadvantages, such as poverty, lacking medicare and unemployment insurance, crime and environmental pollution. Scavengers always live in the suburb and are hard to govern.

Suggestions are: (1) reserve a reasonable population of scavengers in the city; (2) standardize the management of scavengers and support the small or middle sized enterprises to organize scavengers to separate solid waste into three or more categories (combustible, compostable and recyclable waste), compensate for the extra works of scavengers; and (3) integrate the scavengers into the "venous industry" and extend the recycling industrial chain, establish relative policies, criterions, standards and the regulations of supervision, inspection, assessment and encouragement to manage the whole society participating solid waste recycling.

\subsection{Charge for producing solid waste}

Exergy can be used as an index to charge and compensate for producing solid waste. For example, reduction of solid waste and controlling the pollutants of the process of recycling do not have any profit, but the exergetic efficiency of the whole system may be increased due to these operations. It is helpful to establish indices to compare different kinds of contributions or impacts on solid waste management systems, thus exergy can be used as an index and integrated with other indices, such as cost, weight or pollution. Charging or compensating mechanism between different processes and departments (source, collection, transport, recycling, treatment and disposal) should be established to integrate the management of the whole system.

\subsection{Integration of technologies at the end}

According to the exergy analysis, integrating technologies increase the exergetic efficiency at the end of MSW management system. Separation and terminal treatment should be matching and planned holistically. Separation of solid waste is expected to be promoted through developing relative policies, propaganda and education, thus a multifunctional integration of unit technologies should be constructed at the end. there are some considerations in south Beijing's case: (1) some policies have been made to promote safe recycling of restaurant's food waste with higher moisture and oil content, thus a food waste treating factory should be constructed; digestion or biodiesel technologies could be chosen;
(2) it is hard to find a new landfill site around Beijing, exploiting old landfill sites can both reuse the landfill space and recycle manure, metals and plastics in the old sites, thus screening and separating technologies of old landfills should be applied; (3) the biological processes can be accelerated in bioreactor landfill with leachate recirculation or aeration, thus relative facilities should be constructed; and (4) an MSW management system should be constructed at the end with technical integration of landfill, compost, incineration, digestion, biodiesel, screening and separation, bioreactor landfill, etc.

\section{Conclusion}

(1) Exergetic analysis could be used as a scientific tool to objectively and comprehensively assess the MSW management systems.

(2) Exergetic analysis could explain the hierarchy in the MSW management; prevention and separation are on the top of the hierarchy.

(3) Integration of different technologies (separation, recycle, compost, incineration and landfill) could increase the systematic exergetic efficiency.

(4) According to the exergetic analysis, HRRIS aims (harmless, recycling, reductive, industrializing and socializing) of MSW management system were put forward, and scavenger management, charging mechanism and integration of technologies were discussed.

(5) This paper focused on the exergetic assessment of resource transforming; some researches using the exergy method to reflect the environmental impact have been done recently. Hence, a comprehensive exergetic index that integrated different systematic aims could be further discussed.

\section{Acknowledgements}

This research was financially supported by the Key Supporting Project of Ministry of Science and Technology of PR China (2007BAC28B04, 2008BAJ10B05 and 2009BADC2B03), the Knowledge Innovation Project of the Chinese Academy of Sciences (KZCX2-YW-324 and KZCX2-YW-422) and the National Natural Science Foundation of China (70873121). This work was also partially supported by the State Key Laboratory of Urban \& Regional Ecology, Chinese Academy of Sciences (SKLURE2008-101). Thanks are also due to the colleagues of Research Centre of Eco-Environmental Sciences, CAS and the reviewers who help me to improve the paper.

\section{Appendix A}

Tables 4 and 5

Table 4

Component of different diameters of separated municipal solid waste (Rong et al., 2004).

\begin{tabular}{llllll}
\hline Waste & $<15 \mathrm{~mm}$ & $15-60 \mathrm{~mm}$ & $>60 \mathrm{~mm}$ & $<15 \mathrm{~mm}$ and $>60 \mathrm{~mm}$ & All mix \\
\hline Food & $10.00 \%$ & $91.40 \%$ & $35.39 \%$ & $31.07 \%$ & $43.48 \%$ \\
Paper & $0.00 \%$ & $2.10 \%$ & $1.82 \%$ & $1.51 \%$ & $1.63 \%$ \\
Plastic & $0.00 \%$ & $1.85 \%$ & $24.28 \%$ & $20.15 \%$ & $16.38 \%$ \\
Glass & $0.00 \%$ & $2.40 \%$ & $0.80 \%$ & $0.66 \%$ & $1.02 \%$ \\
Stone and & $90.00 \%$ & $1.80 \%$ & $34.20 \%$ & $43.69 \%$ & $35.09 \%$ \\
$\quad$ ash & & & & & \\
Metal & $0.00 \%$ & $0.10 \%$ & $0.47 \%$ & $0.39 \%$ & $0.33 \%$ \\
Wood & $0.00 \%$ & $0.00 \%$ & $3.04 \%$ & $2.52 \%$ & $2.00 \%$ \\
Battery & $0.00 \%$ & $0.35 \%$ & $0.00 \%$ & $0.00 \%$ & $0.07 \%$ \\
\hline
\end{tabular}


Table 5

Parameters for calculating the low heat value of MSW.

\begin{tabular}{llcll}
\hline Waste & $d_{i}$ & HHV $(\mathrm{kJ} / \mathrm{kg})$ & $w_{i}$ & $C_{i}$ \\
\hline Food & 0.444 & 17,000 & 0.66 & 0.21 \\
Paper & 0.356 & 16,000 & 0.47 & 0.47 \\
Plastic & 0.000 & 33,000 & 0.29 & 0.63 \\
Glass & 0.000 & 0 & 0.03 & 0.00 \\
Stone and ash & 0.000 & 0 & 0.10 & 0.00 \\
Metal & 0.000 & 0 & 0.06 & 0.00 \\
Wood & 0.000 & 17,000 & 0.35 & 0.60 \\
\hline
\end{tabular}

\section{References}

Banar, M., Cokaygil, Z., Ozkan, A., 2009. Life cycle assessment of solid waste management options for Eskisehir, Turkey. Waste Management 29, 54-62.

Brown, M.T., Buranakarn, V., 2003. Emergy indices and ratios for sustainable material cycles and recycle options. Resources, Conservation and Recycling $38,1-22$.

Chen, T.C., Lin, C.F., 2008. Greenhouse gases emissions from waste management practices using Life Cycle Inventory model. Journal of Hazardous Materials 155, 23-31.

Contreras, F., Hanaki, K., Aramaki, T., Connors, S., 2008. Application of analytical hierarchy process to analyze stakeholders preferences for municipal solid waste management plans, Boston, USA. Resources, Conservation and Recycling 52, 979-991.

Dewulf, J., Langenhove, H.V., Mulder, J., Berg, M.M.D., Kooi, H.J., Arons, J.S., 2000. Illustrations towards quantifying the sustainability of technology. Green Chemistry $2,108-114$.

Dewulf, J., Langenhove, H.V., 2005. Integrating industrial ecology principles into a set of environmental sustainability indicators for technology assessment. Resources, Conservation and Recycling 43, 419-432.

Dewulf, J., Langenhove, H.V., Dirckx, J., 2001. Exergy analysis in the assessment of the sustainability of waste gas treatment systems. The Science of the Total Environment 273, 41-52.

Dewulf, J., Langenhove, H.V., 2002. Quantitative assessment of solid waste treatment systems in the industrial ecology perspective by exergy analysis. Environmental Science and Technology 36, 1130-1135.

Diaz, R., Warith, M., 2006. Life cycle assessment of municipal solid wastes: development of the WASTED model. Waste Management 26, 886-901.

Eriksson, O., Carlsson Reich, M., Frostell, B., Bjoklund, A., Assefa, G., Sundqvist, J.O., Granath, J., Baky, A., Thyselius, L., 2005. Municipal solid waste management from a systems perspective. Journal of Cleaner Production 13, 241-252.
Finnveden, G., Johansson, J., Lind, P., Moberg, A., 2005. Life cycle assessments of energy from solid waste. Part 1 . General methodology and results. Journal of Cleaner Production 13, 213-229.

IPCC, 2000. Good Practice Guidance and Uncertainty Management in National Greenhouse Gas Inventories. 4-88788r-r000-6.

IPCC, 2001. Climate Change 2001: Work*ing Group I: The Scientific Basis.

Jogensen, S.E., 2010. Ecosystem services, sustainability and thermodynamic indicators. Ecological Complexity 3, 311-313.

Lei, K., Wang, Z., 2008. Municipal wastes and their solar transformities: an emergy synthesis for Macao. Waste Management 28, 2522-2531.

Li, D., Wang, R.S., 2009. Hybrid Emergy-LCA (HEML) based metabolic evaluation of urban residential areas: the case of Beijing, China. Ecological Complexity 4, 484-493.

Marchettini, N., Ridolfi, R., Rustici, M., 2007. An environmental analysis for comparing waste management options and strategies. Waste Management 27, 562 571.

Medina, M., 2000. Scavenger cooperatives in Asia and Latin America. Resources, Conservation and Recycling 31, 51-69.

Nielsen, S.N., 2007. Towards an ecosystem semiotics: some basic aspects for a new research programme. Ecological Complexity 4, 93-101.

Oeler, D., Yetis, U., Demirer, G.N., 2006. Life cycle assessment of municipal solid waste management methods: Ankara case study. Environment International 32, 405-411.

Petrovskaya, N., Petrovskii, S., Li, B.L., 2006. Biodiversity measures revisited. Ecological Complexity 3, 13-22.

Rand, T., Haukohl, J. Amarxen, U., 2000. Municipal solid waste incineration: requirement for a successful project. Word Bank Technical Paper NO. 462. 08213r-r4668-7.

Rong, B., Wei, P., Li, Y., Li, Y., 2004. Composition analysis to Beijing's domestic refuse and corresponding treatment countermeasure. Chinese Environmental Protection 10, 30-33 (in Chinese).

Sciubba, E., 2001. Beyond thermoeconomics? The concept of extended exergy accounting and its application to the analysis and design of thermal systems. Exergy, An International Journal 1, 68-84.

Sciubba, E., Ulgiati, S., 2005. Emergy and exergy analyses: complementary methods or irreducible ideological options? Energy 30, 1953-1988.

Shmelev, S.E., Powell, J.R., 2006. Ecological-economic modelling for strategic regional waste management systems. Ecological Economics 59, 115-130.

Szargut, J., Morris, D.R., Steward, F.R., 1988. Energy Analysis of Thermal, Chemical and Metallurgical Processes. Hemisphere Publishing, New York, 332 pp.

Szargut, J., Ziebik, A., Stanek, W., 2002. Depletion of the non-renewable natural exergy resources as a measure of the ecological cost. Energy Conversion and Management 43, 1149-1163.

Wall, G., 1986. Exergy - A Useful Concept. Chalmers University of Technology, Göteborg, Sweden.

Xu, C., Yang, J.X., Wang, R.S., 2000. Life cycle assessment for municipal solid waste treatment and utilization. Journal of Environmental Sciences 12, 225-231. 